\title{
Real Life Experience of Patients With Locally Advanced Gastric and Gastroesophageal Junction Adenocarcinoma Treated With Neoadjuvant Chemotherapy: a Turkish Oncology Group Study
}

Tugba Basoglu ( $\sim$ basoglutugba@gmail.com )

Marmara Universitesi Tip Fakultesi https://orcid.org/0000-0002-2059-5502

cihan erol

Ankara Yildirim Beyazit University: Ankara Yildirim Beyazit Universitesi

abdullah sakin

Yuzuncu Yil University: Van Yuzuncu Yil Universitesi

ercan özden

Kocaeli University: Kocaeli Universitesi

devrim çabuk

Kocaeli University: Kocaeli Universitesi

ebru çılbır

dışkapı training and research hospital

deniz tataroğlu özyükseler

Istanbul Dr Lufti Kirdar Kartal Egitim ve Arastirma Hastanesi

murat ayhan

Istanbul Dr Lufti Kirdar Kartal Egitim ve Arastirma Hastanesi

mehmet ali şendur

Yıldırım Beyazıt Üniversitesi: Ankara Yildirim Beyazit Universitesi

mutlu doğan

Dr Abdurrahman Yurtaslan Ankara Oncology Training and Research Hospital: Ankara Dr Abdurrahman Yurtaslan Onkoloji Egitim ve Arastirma Hastanesi

berna öksüzoğlu

Dr Abdurrahman Yurtaslan Ankara Oncology Training and Research Hospital: Ankara Dr Abdurrahman Yurtaslan Onkoloji Egitim ve Arastirma Hastanesi

melek karakurt eryılmaz

Necmettin Erbakan University: Necmettin Erbakan Universitesi

özlem er

Acibadem Mehmet Ali Aydinlar University: Acibadem Universitesi

elif şenocak taşçı

Acibadem Mehmet Ali Aydinlar University: Acibadem Universitesi

nelihan doğan

Giresun Training and Research Hospital

özgecan dülgar

Medeniyet Üniversitesi Göztepe Eğitim ve Araştırma Hastanesi: Medeniyet Universitesi Goztepe Egitim ve Arastirma Hastanesi

miraç özen

Sakarya University: Sakarya Universitesi

ilhan hacıbekiroğlu

Sakarya University: Sakarya Universitesi

irem öner

konya city hospital

esma türkmen bekmez 
Kocaeli Derince Training and Research Hospital: Saglik Bilimleri Universitesi Derince Egitim Arastirma Hastanesi

hasan çağrı yıldırım

Hacettepe Universitesi Tip Fakultesi

şuayib yalçın

Hacettepe Universitesi Tip Fakultesi

semra paydaş

Cukurova University Faculty of Medicine: Cukurova Universitesi Tip Fakultesi

emre yekedüz

Ankara University Faculty of Medicine: Ankara Universitesi Tip Fakultesi

asude aksoy

Fırat Üniversitesi Tıp Fakültesi: Firat Universitesi Tip Fakultesi

melike özçelik

Umraniye Training and Research Hospital: Umraniye EAH

abdilkerim oyman

Umraniye Training and Research Hospital: Umraniye EAH

elvina almuradova

Ege University Faculty of Medicine: Ege Universitesi Tip Fakultesi

bülent karabulut

Ege University Faculty of Medicine: Ege Universitesi Tip Fakultesi

nazan demir

Eskisehir Osmangazi Universitesi Tip Fakultesi

murat dinçer

Eskisehir Osmangazi Universitesi Tip Fakultesi

dilek erdem

samsun VM medical park hospital

naziye ak

Istanbul University School of Medicine: Istanbul Universitesi Istanbul Tip Fakultesi

ali inal

mersin city hospital

derya kıvrak salim

Antalya Training and Research Hospital: Antalya Egitim ve Arastirma Hastanesi

gülhan ipek deniz

TC Saglik Bakanligi Istanbul Sisli Hamidiye Etfal Egitim ve Arastirma Hastanesi

ahmet gülmez

İnönü Üniversitesi Tıp Fakültesi: Inonu Universitesi Tip fakultesi

turgut kaçan

Bursa Yüksek İhtisas Eğitim ve Araştırma Hastanesi: Bursa Yuksek Ihtisas Egitim ve Arastirma Hastanesi

özlem özdemir

Izmir Bozyaka Training and Research Hospital: Izmir Bozyaka Egitim ve Arastirma Hastanesi

özkan alan

tekirdağ state hospital

çağlar ünal

Istanbul Florence Nightingale Hospital: Istanbul Florence Nightingale Hastanesi

serdar turhal

istanbul Anadolu Medical Center: Anadolu Saglik Merkezi

yusuf karakaş

Bodrum acıbadem hospital

perran fulden yumuk

Marmara Universitesi Tip Fakultesi 
Research Article

Keywords: Gastric cancer, Gastroesophageal junction cancer, Neoadjuvant chemotherapy, Survival

Posted Date: September 27th, 2021

DOI: https://doi.org/10.21203/rs.3.rs-884239/v1

License: (9) This work is licensed under a Creative Commons Attribution 4.0 International License. Read Full License 


\section{Abstract}

\section{Purpose}

Neoadjuvant chemotherapy(NACT) in gastroesophageal junction(GEJ) and gastric cancer(GC) was shown to improve survival in recent studies. We aimed to share our real-life experience of patients who received NACT in order to compare the efficacy and toxicity profile of different chemotherapy regimens in our country.

\section{Methods}

This retrospective multicenter study included locally advanced GC and GEJ cancer patients who received NACT, and had pathological response evaluation between 2007 and 2021. Relation between CT regimens and pathological evaluation were analyzed.

\section{Results}

A total of 728 patients from 45 oncology centers in Turkey were included. Median age at the time of diagnosis was 60 (range: 1868). Most frequent NACT regimens used were FLOT (65\%), DCF (18\%) and ECF (8.1\%), respectively.

In the total study group pCR rate was $8.2 \%$, R0 resection rate $88.5 \%$, and D2 dissection rate was $66.8 \%$. Rate of pCR and near-CR $(26.4 \%)$, and RO resection (92.6\%) were higher in FLOT arm ( $p=0.005$ and $<0.001)$. Patients who received FLOT had significantly higher chemotherapy-related toxicity rate compared to patients who received other regimens $(p=0.02)$.

Median follow-up time was 17 months (range: 3-106 months). Estimated median overall survival (OS) was 59.4 months ( $95 \% \mathrm{Cl}$ : 32.9-86.0) and disease-free survival (DFS) was 47.6 months (95\% Cl: 24.4-70.8). The highest 5-year estimated OS rate was also shown in FLOT arm (58\%).

\section{Conclusion}

In our real-life study, FLOT regimen has superior survival outcome despite worse toxicity profile. Clinicians should tailor treatment regimens according to patients' multifactorial status and comorbidities for to obtain best outcomes.

\section{Introduction}

Gastric cancer (GC) is an important health problem in Turkey. GC is the fifth common cancer, and the third common cause of cancer related death after lung cancer in our country [1]. In addition GC is also a global problem, as it is the third common cause of cancerrelated death in the world [2]. It is usually diagnosed in an advanced stage [3]. While 5-year survival rates for stage I patients with curative resection are between $70-75 \%$, it decreases to $25-30 \%$ in the locally advanced stage [4]. Therefore, instead of complete resection and lymph node dissection which is known as the only curative treatment in earlier stages, multimodal treatment is a better option for the treatment of locally advanced disease.

Goals of perioperative treatments are to observe the response rates which also gives us hints of the biology of the disease, to eliminate possible micrometastatic disease, to down-stage the primary tumor to increase the chance of RO resection, and finally to improve survival [5-7].

The United Kingdom Medical Research Council (MAGIC) trial was the first large randomized controlled trial to demonstrate significant benefit of perioperative chemotherapy in GC and gastroesophageal junction (GEJ) cancer. In this study patients who received epirubicin, cisplatin, and 5-fluorouracil (ECF) regimen before surgery survived longer than the ones who were only operated [5]. Subsequent study of "Federation Nationale des Centres de Lutte contre le Cancer" (FLNCC) also demonstrated that cisplatin and 5-fluorouracil (CF) regimen in perioperative setting improved survival compared to surgery alone [6]. Finally, perioperative docetaxel, oxaliplatin, 5-Fluorouracil (FLOT) regimen was shown to be superior for survival when it was compared to ECF in the FLOT4-AIO trial [7].

Still best regimen in neoadjuvant setting needs to be tailored for each patient. Many factors are taken into consideration when choosing neoadjuvant chemotherapy (NACT) regimens in our daily practice such as age, performance status and comorbidities of 
patients. Our aim is to share the real-life experiences of patients with gastric and GEJ carcinomas who received different NACT regimens in our country.

\section{Materials And Methods}

We retrospectively evaluated 797 patients with locally advanced (clinical T2 or higher, and/or node positive stage) GC and GEJ adenocarcinoma who were treated with NACT between October 2007-March 2021. The study included 728 patients from 45 different oncology centers in Turkey, who were older than 18 years, were operated after NACT, and had evaluable pathology report. Sixty-three patients who were not operated after NACT, five patients who received neoadjuvant chemoradiotherapy (NACRT), and one patient whose tumor was squamous cell histology were excluded.

Demographic, clinicopathologic, efficacy and side effect data of different NACTs were recorded from their files. Clinical staging at presentation was performed according to American Joint of Committee on Cancer (AJCC) staging 7th edition [8]. Collage of American Pathologists (CAP) -Tumor Regression Grading (TRG) were used for pathological evaluation after surgery [9].

- TRG0: Pathological complete response (pCR): no viable cancer cells;

- TRG1: Near complete response (near CR): single cells or small groups of cancer cells;

- TRG2: Partial response (PR): residual cancer outgrown by fibrosis;

- TRG3: Poor response/no response: minimal or no tumor was killed or extensive residual cancer.

Chemotherapy related toxicities were graded according to Common Terminology Criteria for Adverse Event Version 4.03. Different chemotherapy regimens were compared in terms of efficacy, safety and toxicity.

\section{Statistical Analysis}

All categorical variables were presented as frequencies and group percentages, ranges were denoted for parameters with a median value. Chi-square test was used to compare categorical variables. Univariate and multivariate cox/logistic regression models were conducted to assess factors that predicting survival and pathological response. Overall survival (OS) was defined as the time interval in months between the diagnosis of disease to death or last outpatient visit if the patient was still alive. Disease free survival (DFS) was defined as the time interval in months between the diagnosis of disease to relapse, or last follow-up if patient was not relapsed. OS and DFS were estimated with Kaplan-Meier method and log-rank test. Confidence interval (CI) was selected as $95 \%$ and a 2-sided p value less than 0.05 was accepted as statistically significant. Statistical analyses were performed using SPSS 20.0 software.

\section{Protocols of Chemotherapy Regimens}

FLOT: 5-Fluorouracil, leucovorin, oxaliplatin, docetaxel

Fluorouracil $2600 \mathrm{mg} / \mathrm{m}^{2} \mathrm{IV}$ continuous infusion over 24 hours on Day 1

Leucovorin $200 \mathrm{mg} / \mathrm{m}^{2}$ IV on Day 1

Oxaliplatin $85 \mathrm{mg} / \mathrm{m}^{2} \mathrm{IV}$ on Day 1

Docetaxel $50 \mathrm{mg} / \mathrm{m}^{2} \mathrm{IV}$ on Day 1

Cycled every 14 days

FOLFOX: 5-Fluorouracil, leucovorin, oxaliplatin

Fluorouracil $2400 \mathrm{mg} / \mathrm{m}^{2} \mathrm{IV}$ continuous infusion over 48 hours on Days 1-2

Page 5/17 
Fluorouracil $400 \mathrm{mg} / \mathrm{m}^{2} \mathrm{IV}$ on Day 1

Leucovorin $400 \mathrm{mg} / \mathrm{m}^{2} \mathrm{IV}$ on Day 1

Oxaliplatin $85 \mathrm{mg} / \mathrm{m}^{2} \mathrm{IV}$ on Day 1

Cycled every 14 days

CAPEOX: capecitabine and oxaliplatin

Capecitabine $1000 \mathrm{mg} / \mathrm{m}^{2}$ PO BID on Days 1-14

Oxaliplatin $130 \mathrm{mg} / \mathrm{m}^{2} \mathrm{IV}$ on Day 1

Cycled every 21 days

CF: cisplatin and 5-Fluorouracil

Cisplatin $50 \mathrm{mg} / \mathrm{m}^{2}$ on Day 1

Fluorouracil $2000 \mathrm{mg} / \mathrm{m}^{2}$ IV continuous infusion over 48 hours on Days 1-2

Cycled every 14 days

DCF: docetaxel, cisplatin and 5-Fluorouracil

Docetaxel $75 \mathrm{mg} / \mathrm{m}^{2} \mathrm{IV}$ on Day 1

Cisplatin $75 \mathrm{mg} / \mathrm{m}^{2}$ on Day 1

Fluorouracil $750 \mathrm{mg} / \mathrm{m}^{2}$ daily IV continuous infusion on Days 1-5

Cycled every 21 days

DCX: docetaxel, cisplatin and capecitabine

Docetaxel $60 \mathrm{mg} / \mathrm{m}^{2} \mathrm{IV}$ on Day 1

Cisplatin $60 \mathrm{mg} / \mathrm{m}^{2}$ on Day 1

Capecitabine $1650 \mathrm{mg} / \mathrm{m}^{2}$ PO on Days 1-14

Cycled every 21 days

ECF: epirubicin, cisplatin, and 5-fluorouracil,

Epirubicin $50 \mathrm{mg} / \mathrm{m}^{2} \mathrm{IV}$ on Day 1

Cisplatin $60 \mathrm{mg} / \mathrm{m}^{2} \mathrm{IV}$ on Day 1

Fluorouracil $200 \mathrm{mg} / \mathrm{m}^{2}$ daily IV continuous infusion on Days 1-21

Cycled every 21 days

ECX: epirubicin, cisplatin, and capecitabine

Epirubicin $50 \mathrm{mg} / \mathrm{m}^{2} \mathrm{IV}$ on Day 1 
Cisplatin $60 \mathrm{mg} / \mathrm{m}^{2} \mathrm{IV}$ on Day 1

Capecitabine $825 \mathrm{mg} / \mathrm{m}^{2}$ PO BID on Days $1-14$

Cycled every 21 days

*CAPEOX/FOLFOX, DCF/DCX and ECF/ECX were combined and evaluated as a single group.

\section{Results}

Total of 728 patients with GC/GEJ were included in this study, with a male predominance (72.8\%). Median age at the time of diagnosis was 60 (range: 18-68). Histology was adenocarcinoma in all, and $55 \%$ of patients had gastric primary. All patients were operated and $66.8 \%$ had D2 dissection. Patient and tumor characteristics were described in Table 1.

Mostly used NACT regimens were FLOT (65\%), DCF (18\%) and ECF (8.1\%), respectively. Patients received median of 4 cycles of NACT (range: 2-10). Adjuvant chemotherapy was given to 606 (83.2\%) patients, and 48 of them received additional adjuvant radiotherapy.

Sixty patients (8.2\%) had pCR. Rate of pCR and near-CR (26.4\%), and R0 resection (92.6\%) were higher in FLOT arm ( $p=0.005$ and $<$ 0.001). Efficacy of different chemotherapy regimens according to clinical stage was not different as presented in Table 2 . On the other hand, patients who received FLOT had significantly higher chemotherapy-related toxicity rate compared to patients who received other regimens $(p=0.002)$. Febrile neutropenia was observed in 10 patients after FLOT regimen despite of granulocyte colony-stimulating factor (GCSF) prophylaxis. Comparison of chemotherapy regimens according to pathological response and toxicity profiles are presented in Tables 3 and 4.

Median follow-up time was 17 months (range: 3-106 months). During follow-up, 190 (26.1\%) patients were deceased, and 211 (29\%) relapsed. Estimated three-year OS rate was $60 \%$. Estimated median OS was 59.4 months (95\% Cl: 32.9-86.0) and DFS was 47.6 months (95\% Cl: 24.4-70.8). Although it was not statistically significant, the highest 5-year estimated OS rate was shown in FLOT arm (58\%). Kaplan Meier survival curves presented in Figs. 1 and 2. Three most common relapse sites were peritoneal carcinomatosis (40.8\%), liver metastasis (22.7\%) and loco-regional relapses (10.4\%). Results of survival analysis according to chemotherapy regimens is presented in Table 5.

As we presented in Table 6, positive surgical margins in surgery and no pathological response to NACT were determined as independent poor prognostic factors for both OS and DFS in multivariate analysis.

In addition, not receiving adjuvant treatment was also determined as independent poor prognostic factor for OS.

\section{Discussion}

In recent years, multimodal approach has been preferred in the treatment of GC and GEJ carcinomas which have aggressive biology and poor prognosis. NACT had valuable advantages such as downstaging of tumor, possibly preventing micrometastatic disease, increasing $\mathrm{RO}$ resection rate, and as a result of all improving survival.

In randomized controlled trials, it has been shown that higher rate of R0 resection and D2 dissection improved survival via improving pathological responses [10]. While MAGIC and French FNCLCC/FFCD trials did not include a proper extended lymphadenectomy in the majority of cases, FLOT-AIU trial had mostly D2 dissection. In all these three landmark studies R0 resection rates were higher in selected arms. We observed that $66.8 \%$ of our patients had D2 dissection, and R0 resection rates according to NACT were $92 \%$ with FLOT, $86 \%$ with DCF, $83 \%$ with CF, 78\% with FOLFOX and $73 \%$ with ECF, which were consistent with the literature.

In our pathological evaluation; we observed higher pCR rates with FLOT regimen (9.1\%), but this was lower than $16 \%$ of pCR seen in FLOT4-AIO trial [11]. Near-CR rate was also higher in FLOT4-AIO trial (37\%) than our study (26.4\%).

In FLOT4-AIO trial, distribution of diagnostic age and ECOG-PS were similar with our study. On the other hand, $3.2 \%$ of patients in FLOT4-AIO trial could not be operated due to various reasons. These poor prognostic patient group was excluded from our study 
cohort. In addition, patients having clinical lymph node positive disease were also higher in FLOT4-AIO trial than our study (78\% vs. $55 \%$, respectively). Therefore FLOT4-AIO trial seemed to have more patients with aggressive disease characteristics than our study. Nevertheless, $90 \%$ patients in FLOT4-AIO trial completed all cycles of allocated chemotherapy, while this rate was only $77.4 \%$ in our study. We believe that failure to complete all cycles of chemotherapy is the most important factor affecting our lower pathological response rate.

Perioperative chemotherapy for GE and GEJ adenocarcinoma was shown to improve survival in the literature. First study was reported in 2006, the MAGIC [5] trial showed significant improvement in 5-year OS rate with perioperative ECF treatment over surgery alone (36\% vs 23\%). Second study came out on 2011, French FNCLCC/FFCD trial [6], reported patients who received CF before and after surgery resulting in a significant improvement of 5-year DFS and OS over surgery alone (DFS: $34 \%$ vs $19 \%$, and OS: $38 \%$ vs $24 \%$, respectively). Finally, the FLOT4-AIO trial compared FLOT and ECF/ECX regimens as perioperative treatment in advanced GC and GEJ cancer with clinical resectable tumors, stage cT2 or higher, or nodal positive stage, or both, with no evidence of distant metastases. Results of this landmark study published in 2016 and updated in 2019, showed a 5-year OS rate improvement with FLOT regimen (45\% vs 36\%, respectively) $[7,11,12]$. Besides these randomized trials, Li et al. demonstrated perioperative FOLFOX regimen improved survival [13]. In this prospective non-randomized study, locally advanced GC patients received a total of 6 cycles of FOLFOX chemotherapy perioperatively vs. postoperatively with a 4 -year OS rate of $78 \%$ vs. $51 \%$, respectively. DCF regimen usually investigated on advanced GC and GEJ tumors. V325 Phase II/III trial demonstrated significantly improved OS, time to progression, and quality of life over CF regimen [14]. Two-year survival rate was $18 \%$ with DCF and $9 \%$ with CF. All these pivotal trials summarized in Table 7.

Our study is different from other studies, as we compared five different NACT regimens frequently used in daily practice. In our study population, 1-, 2-, and 5-year estimated survival rates were $89 \%, 72 \%$, and $52 \%$, respectively. According to NACT regimens, estimated 5 -year OS rates were $58 \%$ with FLOT, $55 \%$ with CF, $54 \%$ with DCF and $39 \%$ with ECF, and estimated 3-year OS rate was $70 \%$ for FOLFOX. We observed higher survival rates compared to the literature. Patients who were included in our retrospective cohort were all operated after NACT. Most of the patients with progressive disease on neoadjuvant treatment could not be operated, and expected to live shorter. Also, some might have died during the NACT, either related to side effects or secondary to rapid disease progression. Excluding these patients with primary resistant disease could have affected our results. Besides these, patients having clinical positive lymph nodes $(\mathrm{cN}+)$ who were expected to have poor prognosis were lower in our study population. In addition, our patient cohort had higher D2 dissection rate (66.8\%) that effected higher survival rates.

However, since patients with complete retrospective data were included in the study, patients with possibly had poor prognosis and had incomplete data were excluded due to investigator's bias.

In the literature it has been shown that completion of planned chemotherapy is as important as selected regimen on efficacy. Dose modifications or interrupt treatment and failure to continue with adjuvant chemotherapy adversely affected on survival outcomes.

Although perioperative FLOT is considered as standard-of-care for locally advanced resectable GC and GEJ adenocarcinomas, its' toxicity profile and intolerance jeopardize completion of the planned 8 cycles. Only $46 \%$ of patients completed all cycles (pre and post-operative treatment) in the initial phase 2/3 trial (FLOT-AIO) [11].

Good performance patients were carefully selected for these trials. It was demonstrated that grade 3 or 4 neutropenia was $52 \%$, and febrile neutropenia was $2 \%$ in FLOT-AIU trial. Despite higher primary GCSF prophylaxis in our study (34\% in FLOT-AIU trial, $92 \%$ in ours), we observed higher grade 3 or 4 neutropenia $(62 \%)$ and febrile neutropenia (2.1\%). It may be due to low socioeconomical level and lack off self-care in our country. In our study we also observed grade 3 or 4 chemotherapy-related adverse events and interruption of treatment most frequently with FLOT regimen (28.5\% and 6.3\%).

On the other hand, the least grade 3 or 4 chemotherapy-related adverse events and interruption of treatment was observed with ECF $(11.8 \%$ and $0 \%)$. Most common grade 3 or 4 adverse event was nausea (6.7\%). It was $6.4 \%$ in MAGIC study and $16 \%$ in FLOT-AIU study. Most common toxicity being nausea consistent with the literature, might have been induced by cisplatin.

Adding docetaxel to CF resulted increasing toxicity as well as adding epirubicin to CF has been described in the literature (especially leukopenia for all) $[14,15]$. Hence, CF replaces ECF and DCF in guidelines as neoadjuvant setting. Higher CF toxicity results compared to both ECF and DCF may be due to the small number of patients in that arm in our study. 
Enzinger et al. [16] confirmed in the CALGB 80403/E1206 study, that the FOLFOX regimen had similar effectiveness and better tolerance than the ECF regimen. Efficacy of FOLFOX regimen on neoadjuvant setting was also determined in other recent studies [17-20]. Al-Batran et al. [18] and Vita et al. [20] showed that FOLFOX regimen did not lead more grade 3 or 4 toxicities.

In our study we observed that FOLFOX/CAPEOX regimens are well-tolerated. In this arm, grade 3 or 4 adverse events occurred $15.6 \%$ of patients, and most common side effect was neutropenia (6.1\%). In FOLFOX group, patients older than 65-years was 50\% of the group, and it was higher than other chemotherapy arms. It was striking that FOLFOX was a more tolerable regimen.

The limitations of our study are its' retrospective design and shorter follow-up period. Despite the pathological evaluation was demonstrated one by one ypT and ypN in the landmark trials, we only have combined ypTN data in patients' files. It is difficult for us to compare pathological results in detail. Our survival rates were estimation, and with longer follow-up period, survival results can be altered.

\section{Conclusion}

Here, we investigated perioperative chemotherapy preferences in locally advanced GC and GEJ tumors in our country, and aimed to share the real-life experience in efficacy and tolerability of different regimens. We still do not know which NACT regimen is the best choice for daily practice. Clinicians should be aware of potential side-effects of the regimens and tailor it wisely for the patient. We believe that better results will be obtained with determining correct patient-treatment pairs.

\section{Declarations}

\section{Funding}

No funding has been provided for the preparation of manuscript.

\section{Conflict of Interest}

The authors declare that they have no conflict of interest

\section{Availability of Data and Material}

Available

\section{Ethics Approval}

All procedures performed were in accordance with ethical standards of institutional and/or national research committee, and with the 1964 Helsinki Declaration and its later amendments or comparable ethical standards. Ethical committee approval was obtained from our institute with a number of: 09.2020.1108.

\section{Consent to participate and for publication}

All authors approved the final version of manuscript. They all consent to participate and consent for publication.

\section{Author Contributions}

TB: designed research, analyzed datas, wrote article

CE, AS, EÖ, DÇ, EÇ, DTÖ, MA, MAŞ, MD, BÖ, MKE, ÖE, EŞT, ND, ÖD, MÖ, iH, iÖ, ETB, HÇY, ŞY, SP, EY, AA, MÖ, AO, EA, BK, ND, MD, DE, NA, Al, DKS, AG, TK, ÖÖ, ÖA, ÇÜ, ST, YK: collected datas from their centers

PFY: supervisor of study, designed study, edited english writing

All authors read and approved the manuscript

\section{Acknowledgements}




\section{References}

1. Sung H, Ferlay J, Siegel RL, Laversanne M, Soerjomataram I, Jemal A, et al. Global cancer statistics 2020: GLOBOCAN estimates of incidence and mortality worldwide for 36 cancers in 185 countries. Cancer J Clin. 2021;71(3):209-49.

2. Inghelmann R, Grande E, Francisci S, Verdecchia A, Micheli A, Baili P, et al. Regional estimates of stomach cancer burden in Italy. Tumori. 2007;93(4):367-73. Epub 2007/09/29. PubMed PMID: 17899867.

3. Wang ZL, Wang C, Liu W, et al. Emerging roles of the long non-coding RNA 01296/microRNA-143-3p/MSI2 axis in development of thyroid cancer[J]. Biosci Rep; 2019.

4. De Angelis R, Sant M, Coleman MP, Francisci S, Baili P, Pierannunzio D, et al. Cancer survival in Europe 1999-2007 by country and age: results of EUROCARE-5-a population-based study. The lancet oncology. 2014;15(1):23-34.

5. Cunningham D, Allum WH, Stenning SP, Thompson JN, Van de Velde CJ, Nicolson M, et al. Perioperative chemotherapy versus surgery alone for resectable gastroesophageal cancer. N Engl J Med. 2006;355(1):11-20. doi:10.1056/NEJMoa055531. PubMed PMID: 16822992. Epub 2006/07/11.

6. Ychou M, Boige V, Pignon JP, Conroy T, Bouche O, Lebreton G, et al. Perioperative chemotherapy compared with surgery alone for resectable gastroesophageal adenocarcinoma: an FNCLCC and FFCD multicenter phase III trial. J Clin Oncol. 2011;29(13):1715-21. doi:10.1200/jco.2010.33.0597. PubMed PMID: 21444866. Epub 2011/03/30.

7. Al-Batran S-E, Homann N, Schmalenberg H, Kopp H-G, Haag GM, Luley KB, et al. Perioperative chemotherapy with docetaxel, oxaliplatin, and fluorouracil/leucovorin (FLOT) versus epirubicin, cisplatin, and fluorouracil or capecitabine (ECF/ECX) for resectable gastric or gastroesophageal junction (GEJ) adenocarcinoma (FLOT4-AIO): A multicenter, randomized phase 3 trial. American Society of Clinical Oncology; 2017.

8. Chae S, Lee A, Lee J-H. The effectiveness of the new (7th) UICC N classification in the prognosis evaluation of gastric cancer patients: a comparative study between the 5th/6th and 7th UICC N classification. Gastric cancer. 2011;14(2):166-71.

9. Langer R, Becker K. Tumor regression grading of gastrointestinal cancers after neoadjuvant therapy. Virchows Arch. 2018;472(2):175-86.

10. Fuchs CS, Mayer RJ. Gastric carcinoma. N Engl J Med. 1995;333(1):32-41.

11. Al-Batran S-E, Homann N, Pauligk C, Goetze TO, Meiler J, Kasper S, et al. Perioperative chemotherapy with fluorouracil plus leucovorin, oxaliplatin, and docetaxel versus fluorouracil or capecitabine plus cisplatin and epirubicin for locally advanced, resectable gastric or gastro-oesophageal junction adenocarcinoma (FLOT4): a randomised, phase 2/3 trial. The Lancet. 2019;393(10184):1948-57.

12. Al-Batran S-E, Hofheinz RD, Pauligk C, Kopp H-G, Haag GM, Luley KB, et al. Histopathological regression after neoadjuvant docetaxel, oxaliplatin, fluorouracil, and leucovorin versus epirubicin, cisplatin, and fluorouracil or capecitabine in patients with resectable gastric or gastro-oesophageal junction adenocarcinoma (FLOT4-AIO): results from the phase 2 part of a multicentre, open-label, randomised phase 2/3 trial. The lancet oncology. 2016;17(12):1697-708.

13. Li ZY, Koh CE, Bu ZD, Wu AW, Zhang LH, Wu XJ, et al. Neoadjuvant chemotherapy with FOLFOX: improved outcomes in Chinese patients with locally advanced gastric cancer. J Surg Oncol. 2012;105(8):793-9. doi:10.1002/jso.23009. PubMed PMID: 22189752. Epub 2011/12/23.

14. Ajani JA, Moiseyenko VM, Tjulandin S, Majlis A, Constenla M, Boni C, et al. Clinical Benefit With Docetaxel Plus Fluorouracil and Cisplatin Compared With Cisplatin and Fluorouracil in a Phase III Trial of Advanced Gastric or Gastroesophageal Cancer Adenocarcinoma: The V-325. J Clin Oncol. 2007;25(22):3205-9.

15. Ychou M, Boige V, Pignon J-P, Conroy T, Bouché O, Lebreton G, et al. Perioperative chemotherapy compared with surgery alone for resectable gastroesophageal adenocarcinoma: an FNCLCC and FFCD multicenter phase III trial. Journal of clinical oncology. 2011;29(13):1715-21.

16. Enzinger PC, Burtness BA, Niedzwiecki D, Ye X, Douglas K, Ilson DH, et al. CALGB 80403 (Alliance)/E1206: a randomized phase II study of three chemotherapy regimens plus cetuximab in metastatic esophageal and gastroesophageal junction cancers. J Clin Oncol. 2016;34(23):2736. 
17. Sun Z, Zhu R-J, Yang G-F, Li Y. Neoadjuvant chemotherapy with FOLFOX4 regimen to treat advanced gastric cancer improves survival without increasing adverse events: a retrospective cohort study from a Chinese center. The Scientific World Journal. 2014;2014.

18. Al-Batran S-E, Atmaca A, Hegewisch-Becker S, Jaeger D, Hahnfeld S, Rummel MJ, et al. Phase II trial of biweekly infusional fluorouracil, folinic acid, and oxaliplatin in patients with advanced gastric cancer. Journal of clinical oncology. 2004;22(4):65863.

19. Luo H-Y, Xu R-H, Zhang L, Li Y-H, Shi Y-X, Lin T-Y, et al. A pilot study of oxaliplatin, fluorouracil and folinic acid (FOLFOX-6) as first-line chemotherapy in advanced or recurrent gastric cancer. Chemotherapy. 2008;54(3):228-35.

20. De Vita F, Orditura M, Matano E, Bianco R, Carlomagno C, Infusino S, et al. A phase II study of biweekly oxaliplatin plus infusional 5-fluorouracil and folinic acid (FOLFOX-4) as first-line treatment of advanced gastric cancer patients. British journal of cancer. 2005;92(9):1644-9.

\section{Tables}


Table 1

Characteristics of Patients and Tumors

\begin{tabular}{|c|c|}
\hline Descriptives & $\mathrm{n}=728, \mathrm{n}(\%)$ \\
\hline $\begin{array}{l}\text { Gender } \\
\text { Female } \\
\text { Male }\end{array}$ & $\begin{array}{l}198(27.2) \\
530(72.8)\end{array}$ \\
\hline $\begin{array}{l}\text { ECOG-PS } \\
0 \\
1 \\
2\end{array}$ & $\begin{array}{l}418(57.4) \\
288(39.6) \\
22(3.0)\end{array}$ \\
\hline $\begin{array}{l}\text { Age at Diagnosis } \\
<65 \\
\geq 65\end{array}$ & $\begin{array}{l}506(69.5) \\
222(30.5)\end{array}$ \\
\hline $\begin{array}{l}\text { Smoking History } \\
\text { Current/Past }\end{array}$ & $303(41.6)$ \\
\hline $\begin{array}{l}\text { Location of Tumor } \\
\text { GEJ } \\
\text { Gastric } \\
\text { Fundus } \\
\text { Corpus } \\
\text { Antrum }\end{array}$ & $\begin{array}{l}324(44.5) \\
404(55.5) \\
47(6.5) \\
8(25.8) \\
9(23.2)\end{array}$ \\
\hline $\begin{array}{l}\text { Clinical Stage } \\
\text { cT1-2N+ } \\
\text { cT3-4N0 } \\
\text { cT3-4N+ }\end{array}$ & $\begin{array}{l}26(3.6) \\
328(45.1) \\
374(51.4)\end{array}$ \\
\hline $\begin{array}{l}\text { Type of Surgery } \\
\text { Total gastrectomy } \\
\text { Subtotal gastrectomy } \\
\text { Palliative }\end{array}$ & $\begin{array}{l}511(70.2) \\
208(28.6) \\
9(1.2)\end{array}$ \\
\hline $\begin{array}{l}\text { Lymph Node Dissection } \\
\text { D1 } \\
\text { D2 }\end{array}$ & $\begin{array}{l}242(33.2) \\
486(66.8)\end{array}$ \\
\hline $\begin{array}{l}\text { Resection } \\
\text { R0 } \\
\text { R1 } \\
\text { R2 }\end{array}$ & $\begin{array}{l}644(88.5) \\
55(7.6) \\
29(4)\end{array}$ \\
\hline LVI & $390(53.6)$ \\
\hline PNI & $335(46)$ \\
\hline $\begin{array}{l}\text { Grade Groups } \\
\text { Grade } 1 \\
\text { Grade } 2 \\
\text { Grade } 3\end{array}$ & $\begin{array}{l}53(7.2) \\
387(53.2) \\
261(35.9)\end{array}$ \\
\hline $\begin{array}{l}\text { Pathological Response } \\
\text { CR } \\
\text { Near CR } \\
\text { PR } \\
\text { No response }\end{array}$ & $\begin{array}{l}60(8.2) \\
105(14.4) \\
284(39) \\
279(38.3)\end{array}$ \\
\hline
\end{tabular}


Table 2

Efficacy of Chemotherapy Regimens According to Clinical Stage

\begin{tabular}{|c|c|c|c|}
\hline Chemotherapy Regimens & $\begin{array}{l}\text { cT1-2N+ } \\
n=26(R R \%)\end{array}$ & $\begin{array}{l}\text { cT3-4NO } \\
n=324(R R \%)\end{array}$ & $\begin{array}{l}\text { cT3-4N+ } \\
n=364(R R \%)\end{array}$ \\
\hline FLOT & $4(20)$ & 73(31.9) & $48(21.4)$ \\
\hline FOLFOX/CAPEOX & 0 & $4(19)$ & $1(10)$ \\
\hline DCF/DCX & 1(33.3) & $6(11.5)$ & 14(18.4) \\
\hline $\mathrm{CF} / \mathrm{CX}$ & - & $1(11.1)$ & $2(22.2)$ \\
\hline ECF/ECX & 0 & $1(7.7)$ & $11(24.4)$ \\
\hline$p$ value & 0.85 & 0.05 & 0.84 \\
\hline \multicolumn{4}{|c|}{$\begin{array}{l}\text { FLOT: 5-Fluorouracil, leucovorin, oxaliplatin, docetaxel, FOLFOX: 5-Fluorouracil, leucovorin, oxaliplatin, CAPEOX: capecitabine } \\
\text { and oxaliplatin, CF: cisplatin and 5-Fluorouracil, DCF: docetaxel, cisplatin and 5-Fluorouracil, DCX: docetaxel, cisplatin and } \\
\text { capecitabine, ECF: epirubicin, cisplatin, and 5-fluorouracil, ECX: epirubicin, cisplatin, and capecitabine, RR: response rate } \\
\text { (complete response and near complete response) }\end{array}$} \\
\hline
\end{tabular}

Table 3

Comparison of Chemotherapy Regimens According To Pathological Evaluation

\begin{tabular}{|c|c|c|c|c|c|c|c|c|c|}
\hline \multirow{2}{*}{$\begin{array}{l}\text { Chemotherapy } \\
\text { Regimens }\end{array}$} & \multicolumn{2}{|l|}{ Location } & \multirow{2}{*}{$\begin{array}{l}n= \\
728(\%)\end{array}$} & \multicolumn{3}{|c|}{ Pathological Response } & \multicolumn{3}{|c|}{ Resection Rate } \\
\hline & $\begin{array}{l}\text { GEJ, n } \\
(\%)\end{array}$ & $\begin{array}{l}\text { Gastric, n } \\
(\%)\end{array}$ & & $\begin{array}{l}\text { CR, n } \\
(\%)\end{array}$ & $\begin{array}{l}\text { CR+ } \\
\text { nearCR, n } \\
(\%)\end{array}$ & $\begin{array}{l}\text { PR+ } \\
\text { poor/no } \\
\text { response, } \\
\text { n (\%) }\end{array}$ & RO, n (\%) & $\begin{array}{l}\mathrm{R} 1, \mathrm{n} \\
(\%)\end{array}$ & $\begin{array}{l}\mathrm{R} 2, \mathrm{n} \\
(\%)\end{array}$ \\
\hline FLOT & $223(47.1)$ & $250(52.9)$ & $473(65)$ & $43(9.1)$ & $125(26.4)$ & 163(34.5) & 438(92.6) & $22(4.7)$ & $13(2.7)$ \\
\hline FOLFOX/CAPEOX & $12(37.5)$ & $20(62.5)$ & $32(4.4)$ & $2(6.3)$ & $5(15.6)$ & $13(40.6)$ & $25(78.1)$ & $4(12.5)$ & $3(10.3)$ \\
\hline $\mathrm{DCF} / \mathrm{DCX}$ & $51(38.9)$ & $80(61.1)$ & 131(18) & $7(5.3)$ & 21(16) & $61(46.6)$ & $113(86.3)$ & 15(11.5) & $3(2.3)$ \\
\hline $\mathrm{CF} / \mathrm{CX}$ & $10(55.6)$ & $8(44.4)$ & $18(2.5)$ & $1(5.6)$ & $3(16.7)$ & $9(50)$ & 15(83.3) & $2(11.1)$ & $1(5.6)$ \\
\hline ECF/ECX & $21(35.6)$ & $38(64.4)$ & $59(8.1)$ & $3(5.1)$ & $12(20.3)$ & $28(47.5)$ & $43(72.9)$ & 11(18.6) & $5(8.5)$ \\
\hline \multicolumn{10}{|c|}{$\begin{array}{l}\text { FLOT: 5-Fluorouracil, leucovorin, oxaliplatin, docetaxel, FOLFOX: 5-Fluorouracil, leucovorin, oxaliplatin, CAPEOX: capecitabine } \\
\text { and oxaliplatin, CF: cisplatin and 5-Fluorouracil, DCF: docetaxel, cisplatin and 5-Fluorouracil, DCX: docetaxel, cisplatin and } \\
\text { capecitabine, ECF: epirubicin, cisplatin, and 5-fluorouracil, ECX: epirubicin, cisplatin, and capecitabine, GEJ: gastroesophageal } \\
\text { junction CR: complete response, PR:partial response, RO: microscopically margin-negative resection, R1: microscopically margin- } \\
\text { positive resection, R2: macroscopically margin-positive resection }\end{array}$} \\
\hline
\end{tabular}


Table 4

Comparison of Chemotherapy Regimens According To Toxicity Profiles

\begin{tabular}{|c|c|c|c|c|c|c|}
\hline \multirow{2}{*}{$\begin{array}{l}\text { Chemotherapy } \\
\text { Regimens }\end{array}$} & \multicolumn{2}{|c|}{ Adverse Events, n (\%) } & \multicolumn{2}{|c|}{ Most Common Adverse Events, (\%) } & \multirow{2}{*}{$\begin{array}{l}\mathrm{FN}, \mathrm{n} \\
(\%)\end{array}$} & \multirow{2}{*}{$\begin{array}{l}\text { Stop/Interrupt } \\
\text { treatment, n (\%) }\end{array}$} \\
\hline & $\begin{array}{l}\text { Grade } 1 \\
\text { or } 2\end{array}$ & $\begin{array}{l}\text { Grade } 3 \\
\text { or } 4\end{array}$ & Grade 1 or 2 & Grade 3 or 4 & & \\
\hline FLOT & $228(48.2)$ & $135(28.5)$ & Anemia (71.1) & $\begin{array}{l}\text { Neutropenia } \\
(62)\end{array}$ & $\begin{array}{l}10 \\
(4.3)\end{array}$ & $30(6.3)$ \\
\hline FOLFOX/CAPEOX & 13(40.6) & $5(15.6)$ & Neuropathy (65.8) & $\begin{array}{l}\text { Neutropenia } \\
\text { (19.1) }\end{array}$ & 0 & $1(3.1)$ \\
\hline DCF/DCX & $48(36.6)$ & $32(24.4)$ & Neutropenia (55.5) & $\begin{array}{l}\text { Neutropenia } \\
(42.4)\end{array}$ & 0 & $5(3.8)$ \\
\hline $\mathrm{CF} / \mathrm{CX}$ & $4(22.2)$ & $5(27.8)$ & Trombositopenia (15.2) & $\begin{array}{l}\text { Anemia } \\
(16.7)\end{array}$ & 0 & $0(0)$ \\
\hline ECF/ECX & $31(52.5)$ & $7(11.8)$ & $\begin{array}{l}\text { Neutropenia (15.9), } \\
\text { Nausea (23.1) }\end{array}$ & Nausea (6.7) & 0 & $0(0)$ \\
\hline
\end{tabular}

Table 5

Survival Analysis

\begin{tabular}{|c|c|c|c|c|c|}
\hline $\begin{array}{l}\text { Chemotherapy } \\
\text { regimen }\end{array}$ & $\mathrm{n}(\%)$ & $\begin{array}{l}\text { Median DFS (months) } \\
(95 \% \mathrm{Cl})\end{array}$ & $\begin{array}{l}5 \text { Year DFS Rate } \\
\text { (\%) }\end{array}$ & $\begin{array}{l}\text { Median OS (months) } \\
(95 \% \mathrm{Cl})\end{array}$ & $\begin{array}{l}5 \text { Year OS Rate } \\
(\%)\end{array}$ \\
\hline All patients & $728(100)$ & $\begin{array}{l}47.6 \\
(24.4-70.8)\end{array}$ & 43 & $\begin{array}{l}59.4 \\
(32.9-86.0)\end{array}$ & 52 \\
\hline FLOT & $473(65)$ & $\mathrm{NR}(\mathrm{NR})$ & 53 & $\mathrm{NR}(\mathrm{NR})$ & 58 \\
\hline FOLFOX/CAPEOX & $32(4.4)$ & $N R(N R)$ & - & $\mathrm{NR}(\mathrm{NR})$ & \\
\hline $\mathrm{DCF} / \mathrm{DCX}$ & 131(18) & $\begin{array}{l}85.7 \\
(37.7-133.8)\end{array}$ & 43 & $\begin{array}{l}107.9 \\
(12.3-203.6)\end{array}$ & 54 \\
\hline $\mathrm{CF} / \mathrm{CX}$ & $18(2.5)$ & $N R(N R)$ & 43 & $\mathrm{NR}(\mathrm{NR})$ & 55 \\
\hline ECF/ECX & $59(8.1)$ & $\begin{array}{l}7.6 \\
(19.7-49.6)\end{array}$ & 37 & $\begin{array}{l}37.7 \\
(31.6-43.8)\end{array}$ & 39 \\
\hline
\end{tabular}


Table 6

Univariate and Multivariate Analyses of Factors That Predicting Survival

\begin{tabular}{|c|c|c|c|c|c|c|c|c|}
\hline \multirow[t]{2}{*}{ Factor } & \multicolumn{2}{|c|}{$\begin{array}{l}\text { Univariate analysis } \\
\text { for OS }\end{array}$} & \multicolumn{2}{|c|}{$\begin{array}{l}\text { Univariate analysis } \\
\text { for DFS }\end{array}$} & \multicolumn{2}{|c|}{$\begin{array}{l}\text { Multivariate analysis } \\
\text { for OS }\end{array}$} & \multicolumn{2}{|c|}{$\begin{array}{l}\text { Multivariate analysis } \\
\text { for DFS }\end{array}$} \\
\hline & $\mathrm{HR}(95 \% \mathrm{Cl})$ & $\begin{array}{l}\mathrm{p} \\
\text { value }\end{array}$ & $\mathrm{HR}(95 \% \mathrm{Cl})$ & $\begin{array}{l}\mathrm{P} \\
\text { value }\end{array}$ & HR (95\% Cl) & $\begin{array}{l}\mathrm{p} \\
\text { value }\end{array}$ & HR $(95 \% \mathrm{Cl})$ & $\begin{array}{l}\mathrm{p} \\
\text { value }\end{array}$ \\
\hline $\begin{array}{l}\text { Gender } \\
\text { (male vs. female) }\end{array}$ & $\begin{array}{l}1.28(0.93- \\
1.75)\end{array}$ & 0.003 & $\begin{array}{l}1.26(0.94- \\
1.69)\end{array}$ & 0.12 & $\begin{array}{l}2.0(1.40- \\
3.01)\end{array}$ & 0.10 & - & - \\
\hline $\begin{array}{l}\text { Age at Diagnosis } \\
(\geq 60 \text { vs. }<60)\end{array}$ & $\begin{array}{l}1.23(0.78- \\
1.93)\end{array}$ & 0.366 & $\begin{array}{l}1.04(0.77- \\
1.40)\end{array}$ & 0.79 & - & - & - & - \\
\hline $\begin{array}{l}\text { Clinical Stage } \\
\text { (lymph nodes positive vs. } \\
\text { negative) }\end{array}$ & $\begin{array}{l}1.00(0.75- \\
1.35)\end{array}$ & 0.953 & $\begin{array}{l}1.39(1.05- \\
1.84)\end{array}$ & 0.01 & - & - & $\begin{array}{l}1.29(0.97- \\
1.71)\end{array}$ & 0.73 \\
\hline $\begin{array}{l}\text { Location } \\
\text { (Gastric vs. GEJ) }\end{array}$ & $\begin{array}{l}1.34(0.92- \\
1.97)\end{array}$ & 0.126 & $\begin{array}{l}1.05(0.79- \\
1.38)\end{array}$ & 0.72 & - & - & - & - \\
\hline $\begin{array}{l}\text { Surgical margin } \\
\text { (positive vs. negative) }\end{array}$ & $\begin{array}{l}3.24(1.77- \\
5.91)\end{array}$ & 0.000 & $\begin{array}{l}1.75(1.19- \\
2.58)\end{array}$ & 0.008 & $\begin{array}{l}3.51(2.13- \\
5.78)\end{array}$ & 0.000 & $\begin{array}{l}1.83(1.24- \\
2.70)\end{array}$ & 0.002 \\
\hline $\begin{array}{l}\text { Lymph Nodes Dissection } \\
\text { Type } \\
\text { (D1 vs D2) }\end{array}$ & $\begin{array}{l}1.50(1.02- \\
2.26)\end{array}$ & 0.036 & $\begin{array}{l}1.24(0.94- \\
1.63)\end{array}$ & 0.12 & $\begin{array}{l}1.06(0.73- \\
1.43)\end{array}$ & 0.67 & - & - \\
\hline $\begin{array}{l}\text { Perineural invasion } \\
\text { (yes vs. no) }\end{array}$ & $\begin{array}{l}1.39(0.94- \\
2.04)\end{array}$ & 0.090 & $\begin{array}{l}1.43(1.09- \\
1.88)\end{array}$ & 0.009 & - & - & $\begin{array}{l}1.05(0.76- \\
1.46)\end{array}$ & 0.72 \\
\hline $\begin{array}{l}\text { Lymphovascular invasion } \\
\text { (yes vs. no) }\end{array}$ & $\begin{array}{l}1.29(0.89- \\
2.25)\end{array}$ & 0.075 & $\begin{array}{l}1.50(1.13- \\
1.98)\end{array}$ & 0.004 & - & - & $\begin{array}{l}1.28(0.96- \\
1.71)\end{array}$ & 0.88 \\
\hline $\begin{array}{l}\text { Receiving Adjuvant } \\
\text { Treatment } \\
\text { (no vs. yes) }\end{array}$ & $\begin{array}{l}1.99(1.43- \\
2.77)\end{array}$ & 0.000 & $\begin{array}{l}1.39(0.97- \\
1.98)\end{array}$ & 0.07 & $\begin{array}{l}1.98(1.40- \\
2.79)\end{array}$ & 0.000 & - & - \\
\hline $\begin{array}{l}\text { Pathological Response } \\
\text { (No response vs. Others) } \\
\text { (Others vs Complete } \\
\text { response) }\end{array}$ & $\begin{array}{l}1.90(1.48- \\
2.62) \\
1.97(0.97- \\
4.03)\end{array}$ & $\begin{array}{l}0.000 \\
0.057\end{array}$ & $\begin{array}{l}1.88(1.42- \\
2.44) \\
1.26(0.73- \\
2.17)\end{array}$ & $\begin{array}{l}0.000 \\
0.38\end{array}$ & $\begin{array}{l}2.12(1.59- \\
2.84)\end{array}$ & 0.000 & $\begin{array}{l}1.73(1.30- \\
2.29)\end{array}$ & 0.000 \\
\hline
\end{tabular}


Table 7

Comparison of Pivotal Trials Using Perioperative Treatment

\begin{tabular}{|c|c|c|c|c|c|c|c|}
\hline Trial & $\begin{array}{l}\text { Chemotherapy } \\
\text { regimen }\end{array}$ & $n(\%)$ & $\begin{array}{l}\text { PCR } \\
\text { rate (\%) }\end{array}$ & $\begin{array}{l}\text { D2 } \\
\text { dissection } \\
\text { rate (\%) }\end{array}$ & $\begin{array}{l}\text { RO } \\
\text { resection } \\
\text { rate (\%) }\end{array}$ & $\begin{array}{l}\text { Median DFS } \\
\text { (months); HR } \\
(\% 95 \mathrm{Cl})(\mathrm{p})\end{array}$ & $\begin{array}{l}\text { Median OS } \\
\text { (months); HR } \\
(\% 95 \mathrm{Cl})\end{array}$ \\
\hline MAGIC(5) & $\begin{array}{l}\text { ECF + Surgery } \\
\text { Surgery }\end{array}$ & $\begin{array}{l}250 \\
253\end{array}$ & $\begin{array}{l}\text { Not } \\
\text { reported }\end{array}$ & $\begin{array}{l}42.5 \\
40.4\end{array}$ & $\begin{array}{l}81.9 \\
66.7\end{array}$ & $\begin{array}{l}\text { Estimated surival } \\
\text { rate was given } \\
\text { HR } 0.66(0.53 \text { to } \\
0.81) p<0.001\end{array}$ & $\begin{array}{l}\text { Estimated surival } \\
\text { was given } \\
\text { HR } 0.75(0.60 \text { to } \\
0.93) \\
p=0.009\end{array}$ \\
\hline $\begin{array}{l}\text { French } \\
\text { FNCLCC/FFCD(6) }\end{array}$ & $\begin{array}{l}\text { CF + Surgery } \\
\text { Surgery }\end{array}$ & $\begin{array}{l}113 \\
111\end{array}$ & $\begin{array}{l}\text { Not } \\
\text { reported }\end{array}$ & $\begin{array}{l}\text { Not } \\
\text { reported }\end{array}$ & $\begin{array}{l}84 \\
74\end{array}$ & $\begin{array}{l}\text { HR } 0.65 \text { (0.48 to } \\
0.89) \\
p=0.003\end{array}$ & $\begin{array}{l}\text { HR } 0.69 \text { ( } 0.50 \text { to } \\
0.95) \\
p=0.02\end{array}$ \\
\hline FLOT4/AIO(7) & $\begin{array}{l}\text { FLOT } \\
\text { ECF/ECX }\end{array}$ & $\begin{array}{l}356 \\
360\end{array}$ & $\begin{array}{l}16 \\
6\end{array}$ & $\begin{array}{l}57 \\
53\end{array}$ & $\begin{array}{l}85 \\
78\end{array}$ & $\begin{array}{l}30 \text { months } \\
18 \text { months } \\
\text { HR } 0.75 \text { ( } 0.62 \text { to } \\
0.91) \\
p=0.003\end{array}$ & $\begin{array}{l}50 \text { months } \\
35 \text { months } \\
\text { HR } 0 \cdot 77(0.63 \text { to } \\
0 \cdot 94) \\
p=0.012\end{array}$ \\
\hline Li et al(13) & $\begin{array}{l}\text { Perioperative } \\
\text { FOLFOX } \\
\text { Adjuvant } \\
\text { FOLFOX }\end{array}$ & $\begin{array}{l}36 \\
37\end{array}$ & $\begin{array}{l}6.1 \\
-\end{array}$ & $\begin{array}{l}\text { Not } \\
\text { reported } \\
\text { Not } \\
\text { reported }\end{array}$ & $\begin{array}{l}86 \\
55\end{array}$ & $\begin{array}{l}\text { Survival rate was } \\
\text { given } \\
\mathrm{p}=0.031\end{array}$ & $\begin{array}{l}\text { Survival rates } \\
\text { were given } \\
p=0.022\end{array}$ \\
\hline Basoglu et al & $\begin{array}{l}\text { FLOT } \\
\text { Others }\end{array}$ & $\begin{array}{l}473 \\
255\end{array}$ & $\begin{array}{l}9.1 \\
5.5\end{array}$ & $\begin{array}{l}70.6 \\
59.6\end{array}$ & $\begin{array}{l}68 \\
32\end{array}$ & $\begin{array}{l}N R(N R) \\
47.6 \text { months } \\
(21.6 \text { to } 73.7) \\
\text { HR } 0.93(0.70 \text { to } \\
1.24) p=0.65\end{array}$ & $\begin{array}{l}\text { NR(NR) } \\
59.4 \text { months } \\
(31.2 \text { to } 87.7) \\
\text { HR } 1.0(0.74 \text { to } \\
1.35) \\
p=0.98\end{array}$ \\
\hline \multicolumn{8}{|c|}{$\begin{array}{l}\text { FLOT: 5-Fluorouracil, leucovorin, oxaliplatin, docetaxel, FOLFOX: 5-Fluorouracil, leucovorin, oxaliplatin, CAPEOX: capecitabine } \\
\text { and oxaliplatin, CF: cisplatin and 5-Fluorouracil, DCF: docetaxel, cisplatin and 5-Fluorouracil, DCX: docetaxel, cisplatin and } \\
\text { capecitabine, ECF: epirubicin, cisplatin, and 5-fluorouracil, ECX: epirubicin, cisplatin, and capecitabine, pCR: pathological } \\
\text { complete response, HR: hazard ratio, Cl: Confidence interval }\end{array}$} \\
\hline
\end{tabular}

\section{Figures}




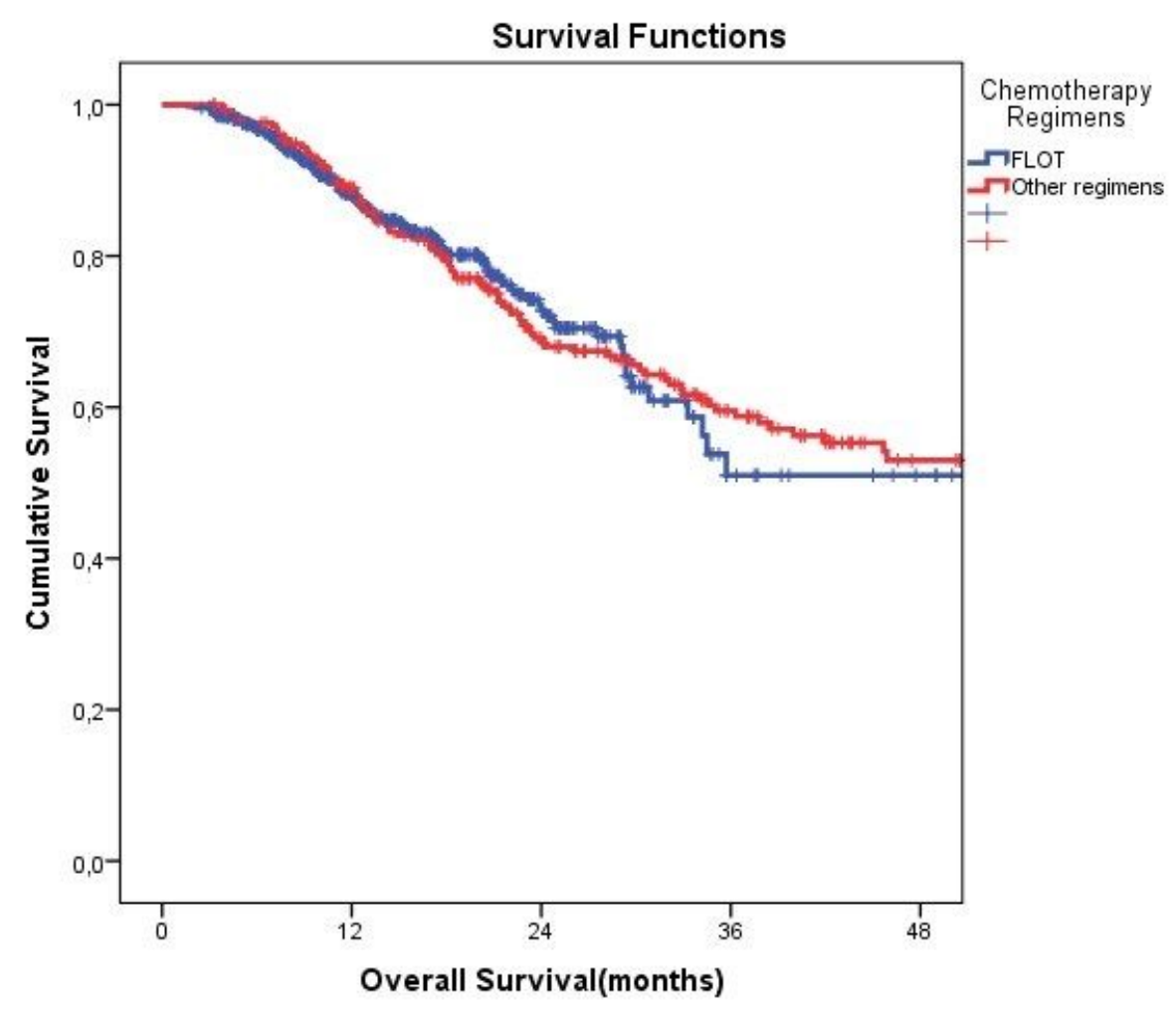

\section{Figure 1}

Kaplan-Meier Curve FLOT vs Other Chemotherapy Regimens Predicting Overall Survival $p=0.98$

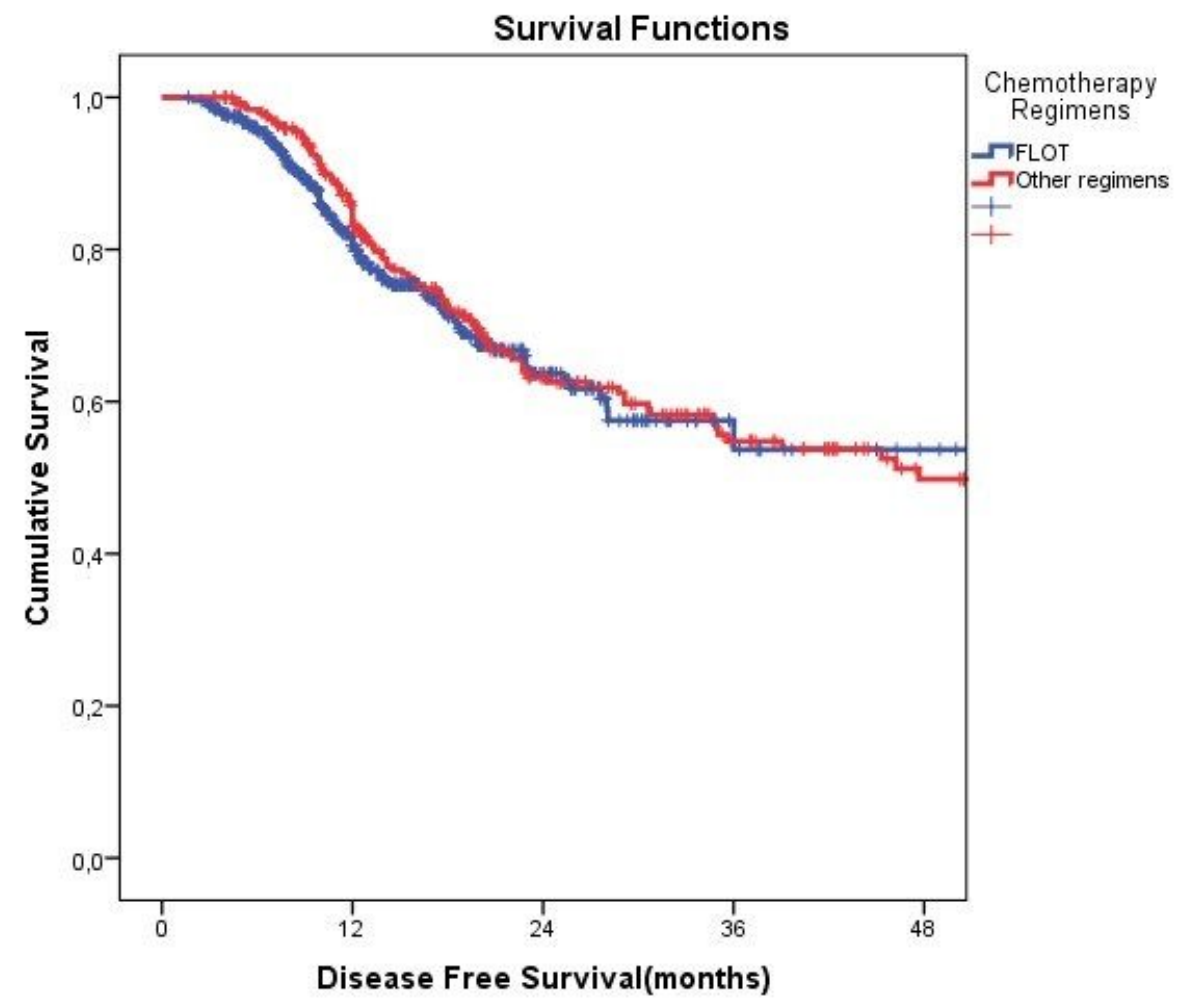

Figure 2

Kaplan-Meier Curve FLOT vs Other Chemotherapy Regimens Predicting Disease Free Survival $p=0.65$ 